\title{
Relationship between Intestinal Helminthiasis and Haemoglobin Level in Ilorin South Local Government Area of Kwara State
}

\author{
T.O. Alade* and Arikekpar Ibemologi \\ Department of Medical Laboratory Science, Faculty of Basic Medical Sciences, College of \\ Health Sciences, Niger Delta University, Bayelsa State, Nigeria \\ *Corresponding author
}

\section{A B S T R A C T}

\begin{tabular}{|l|}
\hline K e y w or d s \\
Helminthiasis, \\
Haemoglobin, \\
$\begin{array}{l}\text { Intestinal parasites, } \\
\text { Anaemia, Children. }\end{array}$ \\
\hline Article Info \\
\hline $\begin{array}{l}\text { Accepted: } \\
\text { 22 February } 2017 \\
\text { Available Online: } \\
\text { 10 March } 2017\end{array}$ \\
\hline
\end{tabular}

In developing countries, prevalence of helminthiasis and anaemia has been one of the major public health problems where they cause micronutrient deficiencies of iron, folate, vitamin $\mathrm{B}_{12}$ and infectious diseases among children. Faecal samples and blood samples were obtained from 258 children. Faecal samples were examined using standard parasitological techniques, and anaemia was defined as blood haemoglobin $<10 \mathrm{~g} / \mathrm{dL}$. Eighty five patients representing $47.2 \%$ were positive for hookworm, while $62(34.4 \%)$ of the patients for Ascaris lumbricoides (A. lumbricoides). Trichuris trichiura (T. trichiura) was ranked third most positive with 25 (14\%), followed by Schistosoma mansoni ( . mansoni) with only $8(4.4 \%)$ testing positive. Eighty six patients representing $48 \%$ who tested positive for helminthes had $\mathrm{Hb}<10 \mathrm{~g} / \mathrm{dl}$ and were considered anaemic, while 94 (52) also tested positive for helminthes but had $\mathrm{Hb}>10 \mathrm{~g} / \mathrm{dl}$ and were considered non anaemic. Sixteen of the patients representing $29 \%$ who tested negative for helminthes had $\mathrm{Hb}<10 \mathrm{~g} / \mathrm{dl}$ (anaemic) while 62(79\%) patients who tested negative had $\mathrm{Hb}>10 \mathrm{~g} / \mathrm{dl}$ (non anaemic). Public enlightenment programmes should be carried out on personal and good hygiene at controlling of intestinal helminth infection and anaemia.

\section{Introduction}

Helminthiasis has continued for many years to be a world health problem in many developed countries. World populations of people that are infected with intestinal worms have been reported to be 1.47 billion, 170million and 300million for roundworm, hookworm and whipworm respectively (Ibrahium, 2011). Studies had shown that helminthes in the course of their infestation may cause adverse and pathogenic effect on their host (World Health Organization, 2002). The intestinal helminthes are those worms which may inhabit the intestinal tract of man and animal as their predilection site where they derive nourishment (McGregor et al., 1996) and their larvae can migrate to other organs causing physiological damages. These helminthes are transmitted via eggs that are passed in the faeces of infected persons that attach to vegetables or contaminated water sources and then ingested or eggs can hatch releasing larvae that penetrate the skin (World Health Organization, 2017). Their geographical distribution depends on the species life cycle, climatic as well as other conditions; A. lumbricoides, T. trichiura, Necator americanus and Ancylostoma duodenale infect more than a billion people 
and the most serious helminth infections are prevalent in poor tropical and subtropical areas (de Silva et al., 2003).

Very few helminthes are known to be potentially dangerous and most are pathogenic only when worm loads are high. Some individual tolerate these parasite even with very heavy worm loads, but others may show quite severe clinical manifestation. In extreme cases where the worms feed on or pierce through tissues much harm or even death may result from severe damage to the host cell. One of the ways in which pathogenesis may occur is anaemia (Chatterjee et al., 2014).

Helminths such as hookworms can cause iron deficiency anaemia via blood loss because adult hookworms attach themselves to the gut wall ingesting both the gut wall cells and blood. Every 4-6 hours feeding sites are changed with secretion an anticoagulant, resulting in secondary blood loss from the damaged gut wall after the worms have stopped feeding (Koukounari et al., 2008). Anaemia itself is not a disease but a sign of an underlying disorder which cause should be identified and it constitutes major public health problems in many developing countries. Efficient correction of anaemia depends on the discovery of the pathological factors causing it. Anaemia could be primarily brought about by chronic blood loss but some other factors have to be taken into consideration to explain the development and types of anaemia, such as nutritional effects Anemia is a condition where there is less than the normal hemoglobin $(\mathrm{Hb})$ level in the body, which decreases oxygen-carrying capacity (Osazuwa et al., 2011). Different factors cause anaemia but nutritional deficiency is the most important cause worldwide with iron deficiency anaemia as the main source of nutrition related anaemia. Some effects of anaemia are lower birth weight babies who have a higher risk of death, reduced work productivity in adults and limits cognitive development in children, impaired gastrointestinal functions and adverse effects on the immune system resulting in reduced resistance to infections.

Hookworm is capable of drawing from 0.03$0.2 \mathrm{ml}$ of blood per day and Infestation with other worms, for example Trichuris trichiura, also cause significant blood loss (Kaeni, 2003) A. lumbricoides which is usually regarded as the most common helminthes of man is estimated to infect about $25 \%$ of the world population and may cause perforation of the intestinal wall or may penetrate the parenchyma of the liver or even lungs and the most common complication is intestinal obstruction due to worm bolus (Arif et al., 2011). Efficient diagnosis of anaemia depends on the haemoglobin concentration by standard method and absolute recovery of ova, larva or adult worms and in the stool of the patient. This is compared with the normal haemoglobin level which varies with age and sex.

\section{Materials and Methods}

\section{Study area}

Ilorin, the capital of Kwara state is situated $360 \mathrm{~km}$ north of Lagos, at $0830 \mathrm{~N}$ and $0430 \mathrm{~N}$ and 482KM South West from Abuja. It is the gateway between the northern and southern part of the country. The population which is estimated to be 2-3 million is made up of four main ethnic groups, namely Yoruba, Nupe, Fulani and Baruba. Kwara states shares boundary with Ekiti, Oyo, Osun, Kogi and Niger state

\section{Sample collection}

Faecal samples and blood samples were obtained from 258 children in Ilorin. Faecal samples were examined using standard 
parasitological techniques, and anaemia was defined as blood haemoglobin $<10 \mathrm{~g} / \mathrm{dL}$. Direct smear of the stool sample was made on a clean grease-free slide, covered with cover slips and was examined for ova of parasite under the microscope using x10 and $\mathrm{x} 40$ objective lens Samples that were negative for parasite ova and cysts were subjected to a concentration method as described by the World Health Organization.

The formal ether concentration technique was used. A $1 \mathrm{~g}$ sample of the stool was emulsified in $5 \mathrm{~mL}$ of formal saline, sieved, and the suspension collected in a centrifuge tube, followed by the addition of $3 \mathrm{~mL}$ of ether. The well-mixed suspension was centrifuged at $3000 \mathrm{rpm}$ for 1 minute. The supernatant was discarded, and the sediment examined microscopically using $10 \mathrm{X}$ and $40 \mathrm{X}$ estimation of haemoglobin using cyanmet haemoglobin method.

Consents were obtained from the parents of the respective subjects for the purpose of this research.

\section{Data analysis}

Data analysis of the different prevalence was carried out with simple percentage

\section{Results and Discussion}

The investigation revealed that 85 patients representing $47.2 \%$ were positive for hookworm, while 62 (34.4\%) of the patients for A. lumbricoides. T. trichiura was ranked third most positive with 25 (14\%), followed by $S$. mansoni with only $8(4.4 \%)$ testing positive (Table 1).

Eighty six patients representing $48 \%$ who tested positive for helminthes had $\mathrm{Hb}<10 \mathrm{~g} / \mathrm{dl}$ and were considered anaemic, while 94 (52) also tested positive for helminthes but had $\mathrm{Hb}$ $>10 \mathrm{~g} / \mathrm{dl}$ and were considered non anaemic. Sixteen of the patients representing $29 \%$ who tested negative for helminthes had $\mathrm{Hb}<10 \mathrm{~g} / \mathrm{dl}$ (anaemic) while 62(79\%) patients who tested negative had $\mathrm{Hb}>10 \mathrm{~g} / \mathrm{dl}$ (non anaemic) (Table 2).

Table.1 Distribution of intestinal helminthes

\begin{tabular}{ll}
\hline PARASITE & NO. POSITIVE (\%) \\
\hline Hookworm & $85(47.2)$ \\
Ascaris lumbricoides & $62(34.4)$ \\
Trichuris trichiura & $25(14.0)$ \\
Schistosoma mansoni & $8(4.4)$ \\
\hline Total & $\mathbf{1 8 0}(\mathbf{7 0 . 0})$ \\
\hline
\end{tabular}

Table.2 Distribution of helminthes and haemoglobin level in subjects

\begin{tabular}{llll}
\hline Helminthes & $\begin{array}{l}\text { NO\% Anaemic } \\
(\text { Hb }<\mathbf{1 0 g} / \text { dl })\end{array}$ & $\begin{array}{l}\text { No(\%)Nonanaemic } \\
(\text { Hb }>\mathbf{1 0 g} / \text { dl })\end{array}$ & Total \\
\hline+ Present & $86(48)$ & $94(52)$ & $\mathbf{1 8 0}$ \\
-Absent & $16(21)$ & $62(79)$ & $\mathbf{7 8}$ \\
Total & $\mathbf{1 0 2}(40)$ & $\mathbf{1 5 6}(\mathbf{6 0})$ & $\mathbf{2 5 8}$ \\
\hline
\end{tabular}


The total helminthes prevalence observed in Ilorin South Local Government area is $70 \%$, this is similar though lower when compared to the work of Wosu and Onyeabor (Wosu et al., 2014), where they recorded $75.7 \%$ on the prevalence of Intestinal Parasite Infections among School Children in a Tropical Rainforest Community of Southeastern Nigeria. The present research revealed a very high prevalence rate of helminthes which could be as a result of poor hygiene practices among the pupils which enhanced transmission through to fecal-oral route contamination.

In the classes of helminthes, hookworm was most prevalent with $42.7 \%$ which agrees with Ejezie et al., (1993) where they recorded $45.5 \%$ but did not agree with Osazuwa et al., (2011) and Odebunmi et al., (2007) where they recorded $16.19 \%$ and $3.2 \%$ respectively. In this study, hookworm is considered as an independent risk factor for anaemia. $A$. lumbricoides was $34.4 \%$ which is higher than $22.7 \%$ as reported by Wosu and Onyeabor but was lower than $75.6 \%$ reported by Osazuwa et al., (2011). A prevalence of T. trichiura $14 \%$ was recorded in the present research which corresponds with the low prevalence $7.5 \%$ and $3.2 \%$ reported by Osazuwa et al., and Ekpenyong et al., (2008) respectively, but disagrees with the research of Wosu and Onyeabor who reported 34.5\%. Least prevalent in our study is $S$. mansoni $(4.4 \%)$, which agrees with a study on primary school level, 6(4.29\%) and secondary school $7(5.00 \%)$ by Goselle et al., (2010).

In conclusion, the overall helminthes prevalence rate in Ilorin South local Government area was $70.0 \%$ as determined by egg positive stools. This is higher than in some other tropical areas where as low as $26.0 \%$ have been recorded. Anaemia in Ilorin local government is statistically related to Intestinal helminthiasis, hookworm and $T$. trichuira are related than A. lumbricoides. Public health measures should be given serious attentions to, educating the public on personal and good hygiene as well as the consequences of anaemia.

\section{References}

Arif, H., Fazl, Q., Hakim, I., Yasir, A. and Naseer, A. 2011. Case report in infectious diseases. htpp://dx.doi.org/10.1155/2011/512607

Chatterjee, N. and G. Fernandes. 2014. This is normal during pregnancy': A qualitative study of anaemia-related perceptions and practices among pregnant women in Mumbai, India. Midwifery, 30(3): 56-63.

de Silva, N.R., Brooker, S., Hotez, P.J., Montresor, A., Engels, D., Raviolis, L. 2003. Soil-transmitted helminth infections: updating the global picture. Trends Parasitol., 19(12): 547-551.

Ejezie, G.C., Emeribe, A.O. and Igwe, M.A. 1993. Human Ecology and Parasitic Infections in Nigeria and Relationship between Parasitic Infections and Anaemia. J. Med. Lab. Sci., 3: 22-2.

Ekpenyong, E.A. and Eyo, J.E. 2008. Prevalence of intestinal helminths infections among schooling children in tropical semi Urban communities, Animal Res. Int., 5(1): 804 - 810.

Goselle, N.O., Anegbe, G.N., Imandeh, D.A., Dakul, A.C., Onwuliri, O.J., Abba, O.E. and Abelau, A.M. 2010. Schistosoma mansoni infections amongst school children in Jos, Nigeria. Sci. World J., 5(1).

Ibrahium, F. 2011. Prevalence and predisposing factors regarding intestinal parasitic Infections among rural primary school pupils at Minia Governorate, Egypt, J. Public Health in Africa, doi: http://dx.doi.org/10.4081/jphia.2011.e29.

Kaeni Agiomea. 2003. Anaesthetic considerations in patients with parasitic 
diseases and anaemia, Pp. 1-8.

Koukounari, A., Estambale, B.B., Njagi, J.K., Cundill, B., Ajanga, A., Crudder, C., Otido, J., Jukes, M.C., Clarke, S.E. and Brooker, S. 2008. Relationships between anaemia and parasitic infections in Kenyan schoolchildren: a Bayesian hierarchical modelling approach. Int. J. Parasitol., 38: 1663-7.

Kriviene, I. and Ragelienè, L. 2006. The prevalence of anemia among schoolchildren in Šauliai region of Lithuania. Acta Med. Lituan, 13: 56-5.

Leenstra, T., Kariuki, S.K., Kurtis, J.D., Oloo, A.J., Kager, P.A. and ter Kuile, F.O. 2004. Prevalence and severity of anemia and iron deficiency: cross-sectional studies in adolescent schoolgirls in western Kenya. Eur. J. Clin. Nutr., 58: 681-91.

Maria, R.F., Wayner, S., Emelia, P., Tiago, L., Alexandre, B.C., Andre, .F, Helio, B.C. and Derek, W. 1998. Intestinal helminthiasis and anaemia in youngsters from Matriz da Luz, Brazil. Mem. Inst. Oswaldo Cruz, 93(3): 289-293.

McGregor, I.A., Williams, K., Brilleanien,
N.C. and Thompson, A.M. 1996. Haemoglobin concentration and anaemia in young West African Children. Trans Roy Soc. Trop. Med. Hyg., 60: 650-67.

Odebunmi, J.F., Adefioye, O.A. and Adeyeba, A. 2007. Hookworm infection among school children in Vom, Plateau state Nigeria. American Eurasian J. Sci. Res., 1: 39-42.

Osazuwa, F., Oguntade, M. and Paul, I. 2011. A significant association between intestinal helminth infection and anaemia burden in children in rural communities of Edo state, Nigeria. N Am. J. Med. Sci., 3(1): 30-34.

World Health Organization. 2017. Soil transmitted helminth infection fact sheet.

World Health Organization. 2002. Prevention and Control of Schistosomiasis and SoilTransmitted Helminthiasis. WHO Technical Series Report 912. Geneva.

Wosu, M.I. and Onyeabor, A.I. 2014. The prevalence of intestinal parasite infections among school children in a tropical rainforest community of southeastern Nigeria, J. Anim. Sci. Adv., 4(8): 1004-1008.

\section{How to cite this article:}

Alade, T.O. and Arikekpar Ibemologi. 2017. Relationship between Intestinal Helminthiasis and Haemoglobin Level in Ilorin South Local Government Area of Kwara State. Int.J.Curr.Microbiol.App.Sci. 6(3): 1456-1460. doi: https://doi.org/10.20546/ijcmas.2017.603.166 